\title{
A son in heaven, but no father on earth: A note in the margin of a 'Tale of Two Kings'
}

\begin{abstract}
Author:
Joseph Verheyden ${ }^{1,2}$

Affiliations:

${ }^{1}$ Faculty of Theology,

Catholic University of

Leuven, Belgium

${ }^{2}$ Faculty of Theology,

University of Pretoria,

South Africa

Note:

Prof. Dr Joseph Verheyden participates in the research project 'Biblical Theology and Hermeneutics', directed by Prof. Dr Andries G. van Aarde, Honorary Professor of the Faculty of Theology at the University of Pretoria, South Africa.

Correspondence to:

Joseph Verheyden

email:

jos.verheyden@theo.

kuleuven.be

Postal address:

Faculty of Theology, Catholic University of Leuven, St-Michielsstraat 4/3101, B-3000, Belgium

Dates:

Received: 23 July 2010 Accepted: 28 July 2010

Published: 07 June 2011

How to cite this article: Verheyden, J., 2011, 'A son in heaven, but no father on earth: A note in the margin of a "Tale of Two Kings"', HTS Teologiese Studies/ Theological Studies 67(1), Art. \#928, 6 pages. DOI: 10.4102/hts.v67i1.928
\end{abstract}

(C) 2011. The Authors. Licensee: OpenJournals Publishing. This work is licensed under the Creative Commons Attribution License.
The article is meant to offer a comment on the thesis of Andries G. van Aarde about the socalled fatherlessness of Jesus. The author argues for a more critical disposition towards a historical-psychological approach of ancient texts. Jesus' attitude towards children, which is illustrated in Mark 10:13-16, and the story of Jesus' birth and of Herod's reaction to it as told by Matthew, are used as test cases.

\section{Introduction}

Fatherless in Galilee, Andries van Aarde's historical-psychological reading of Jesus' life and ministry on the hypothesis that he was raised without a father and was deeply marked by it, appeared in 2001. Some time after the author graciously provided me with a copy of the book, I read it and made some annotations in the left and right margins. I re-read the book in preparing for this article, looked at my comments again and picked one that I would like to develop somewhat further. I finally decided on the sixth chapter, which bears the title 'Defending the Fatherless' and will make two comments. However, I will begin with a preliminary note on methodology.

Van Aarde begins his monograph on an autobiographical note with a forty-page chapter on 'His Journey'. It informs the reader about certain events and experiences from the personal and academic life of the author that have shaped the book and its contents. The early death of the author's father is one such element, the struggle with historical Jesus research from past and present is an equally important one; so is also the participation in the work of the Context Group and what it meant for the author gradually becoming aware of the gains that can be found for biblical studies in multi- and interdisciplinary research. As a consequence of the latter, the reader of Fatherless in Galilee will discover that a good number of Van Aarde's observations and comments are informed by methods and results borrowed from the social sciences. Sociology takes a place of honour, but social anthropology and even ethnology do play their role as well. All this is reflected in the way Van Aarde describes the method (or methods) he has been using. It is evident from this first chapter that historical-critical research 'proper' is not given up, but it is now conducted within different matrixes that include methods and approaches from the social sciences in explaining the biblical texts. As far as I can see, a formal definition is lacking, but the following comes close to it: 'The interdisciplinary aspect in this new development relates to archaeological, socio-historical and cultural-anthropological studies. But it does not mean that historical research as such is now dismissed' (Van Aarde 2001:31). The importance of this move and its implications for understanding these ancient texts are duly emphasised in the last lines of this first chapter: 'Social-scientific criticism, however, makes us aware not only of cross-cultural similarities, but also of differences in cosmology, ideology, and mythology' (Van Aarde 2001:40). Whilst there is truth in both these statements, readers working their way through the book might in the end have the impression that one more discipline should perhaps have been given a more prominent place in describing the method that has been used.

In addition to sociology, a good deal of (social) psychology is also at work. That is why I have called Van Aarde's method 'a historical-psychological reading' in the opening lines of this note. Of course, to many 'psychological reading' has become a burdening term, one that evokes visions of those abhorred 'psycho-pathological' studies of the historical Jesus from a far past and what they have provoked of anger and contempt (Van Aarde 2001:15-16), or of 'psychoanalytical' readings of a less distant past and what such studies have raised of unbelief and irritation. ${ }^{1}$ However, it would seem that recently some scholars have been trying to put off the past and have gone at work again with an approach that is primarily informed by specific disciplines from the broader field of psychology, amongst them, social psychology and developmental psychology, but that also explicitly wants to link in with historical Jesus research. Van Aarde is familiar with this approach. He shows himself to be a critical reader of it, though it would

1.As it tends completely to disregard the historical component, Van Aarde does not mention this approach. 
seem it is not the method itself, but the way it is applied by some that causes him problems. Thus, he notes with regard to John W. Miller's (1997) Jesus at Thirty, 'My uneasiness with Miller's psychohistorical analysis of Jesus concerns not his use of psychology as such'. In addition, he again calls upon Schweitzer to indicate what the problem then is:

In a similar way, the bottom line of Albert Schweitzer's protest against the psychopathological studies of Jesus was not whether their psychoanalytical theories were correct. Of course, these psychoanalytical theories should have been tested, as Schweitzer the medically trained psychiatrist did. As a biblical scholar, he was concerned about the unsophisticated historical analyses of the textual evidence in the New Testament found in these studies.

(Van Aarde 2001:79-80)

The concern has to do with the historical component, which is not lacking in such studies, but which Van Aarde thinks has been misread or misconstrued by Miller. Van Aarde's monograph has not gone unnoticed amongst scholars working with methods and approaches derived from the field of psychology. ${ }^{2}$ So there may be some good reason (also) to use the label 'psycho-historical' or 'psycho-biographical'; better still, in my opinion, 'historical-psychological', for the historical aspect and what can be known about it from the biblical text and possibly derived from other ancient literature, remains a prime interest of the author all through the monograph. Therefore, it is to the text that I now shall turn.

\section{Matthew 2:13-16}

In the sixth chapter of the book, Van Aarde (2001:135-154) addresses two topics that in his view are related and can be explained from each other. The first one has to do with Jesus' attitude towards children, which is illustrated in Mark 10:1316; the other with the story of Jesus' birth and of Herod's reaction to it as told by Matthew. The latter is entitled 'A Tale of Two Kings' and the first one 'Jesus - Kingdom of God - Children'. This same complex and 'fundamental social setting' as in Mark is also behind Matthew's version of the Evangelium Infantium in Matthew 19:13-15. According to Van Aarde (2001:149), 'the same social setting can be assumed to be part of the background of the narrative about the birth of Jesus, at least as told in Matthew's story'. The latter reflects Matthew's struggle with a Jesus he knew was suspected to be an illegitimate child, hence a person with no honour. The solution he offers is quite a surprising one. He does not try to hide, deny or ignore the charge, but he plays on the theme in such a way that it turns out to be a matter of honour and pride, at least on the new terms that for him come to replace the old values. Honour, with God, is not a matter of genealogy. To stress the point Matthew does not try to 'clean up' the record, but instead gives Jesus' antecedents 'as they really were'. The result is a genealogy that contains a

2.Thanks are due to $\mathrm{Dr}$ Bas van Os (Utrecht) for drawing my attention to this literature in a paper he gave at the annual Conventus of Dutch and Flemish New Testament scholars at Soesterber on June 14,2010. The title of his paper was 'The Role scholars at Soesterberg on June 14, 2010. The title of his paper was 'The Role of Psychology in the Search for the Historical Jesus and His Earliest Followers'. Van Os critically discusses the views of John Miller (Jesus at Thirty), Donald Capps (Jesus: Psychological Biography) and Van Aarde and finds these incompatible; yet he also tries to keep an open eye for what could be gained by such an approach. The paper is part of a larger project van Os is currently working on. Fatherless in Galilee is also summarised and discussed in Ellens (2004). couple of names, all of them women, with a rather disputable reputation in the eyes of many a Jewish reader. In addition, Matthew emphasises the point that Mary's pregnancy happened by God's intervention; and it was this same instance that made Joseph adopt Jesus as his foster child and the man is honoured for it and called 'son of David' (1:20). ${ }^{3}$ As Van Aarde notes, 'According to Matthew, God was the one who intervened on behalf of Jesus' (Van Aarde 2001:150). That is what makes the difference and that is what counts. A person is 'not characterised primarily by biological offspring, but by what he would do, his vocation' (Van Aarde 2001:151). Matthew then goes on contrasting this child to its first enemy and opponent, King Herod the Great, who wishes to counter the claims about a Jewish king being born in Bethlehem that were made by the magi and confirmed by his own priests and scribes. Jesus escapes his fate twice, each time again protected by God's intervention. Herod's plan to kill the child is aborted for lack of information because the magi warned in a dream do not return to the court. It only brings out the worst in him and the king, who does not like half measures, takes to the most radical act of mass infanticide.

My comment is not about the genealogy, but about the infanticide. When I read this section for the first time, I scribbled in the margin, 'Where is Moses?' Indeed, Matthew 2:13-16 is not just a story about a poor and helpless child that is divinely protected. Moreover, it is more than a story about an evil king who wants to protect himself against anyone who might possibly claim one day to challenge his position. This story, because of the echoes it contains to Exodus 2:1-10, carries the message that a new Moses is born. It is the first instance of a Moses typology that will run all through Matthew's gospel and squarely place Jesus in a story and a history that goes all the way back to Moses. ${ }^{4}$ There is a third player in the game, besides Jesus and Herod. The link between Matthew 2:13-16 and Exodus 2 has been noted by many commentators. Most recently it has been discussed again by Christina Tuor-Kurth (2010:209-213) in a monograph on the praxis of exposing children in antiquity. She refers to Broer, Cohen, Mayordomo-Marin and Fiedler, but the explanation is a far more common one than these few names might suggest and it has a much longer history that might be worth tracing in more detail than can be done here (Broer 1977-1978:50-53, 1981:83-87; Cohen 1993:157171; Mayordomo-Marin 1998: 312-314; Fiedler 2006:54). ${ }^{5}$ The link is not an indirect or purely allusive one, even though Matthew does not explicitly call Moses by name. As Tuor-

3. Matthew makes it very clear to the reader that Jesus is not Joseph's natural son. Most tellingly, when Joseph is instructed by the angel s is never called 'your son' but always a son'. At one point a few copyists seem to have 'sinned' against this rule: in 1:21 sy. have added 'for you' to Té $\xi \in T a l$ Sé vióv ['she will bear a son']. The variant may have been inspired by 1:18 (Joseph is 'betrothed' to Mary), or rather by Genesis 17:19 and God's promise to Abraham that his wife 'shall bear you a son'. By adding the pronoun Jesus is made the son of Joseph, more than originally was perhaps intended. The variant fits well in combination with the missive that Joseph will call him by the name of Jesus. At least that is granted to him, that he can give 'his son' his name. Always on the defence for the Old Syriac Merx (1902:24) not surprisingly wonders how the Greek could possibly be regarded as the original: 'Kein Grieche und kein Lateiner hat es. Soll hier, wo der Grund der Weglassung handgreiflich ist, die griechisch-lateinische Masse gegen die zwei Syrer in's Feld geführt werden? Und was folgt daraus für die Beurteilung von aB?'

4.On Moses typology in Matthew see above all, Allison (1993:140-165).

5.The history of this exegesis goes back well into the Patristic era. Cf. Allison (1993:141) citing from Ephraem (Hymn 24) and especially Aphraates (Dem. 21.10): 'Moses also was persecuted, as Jesus was persecuted'. 'Commentary would be superfluous' (Allison 1993:141). 


\section{Kurth (2010) notes:}

die inhaltlichen wie sprachlichen Anlehnungen an Ex 2,15 und 4,19 bei den Erzählmomenten der Flucht nacht Ägypten (Mt $2,13)$ und der Rückkehr von dort $(2,19 \mathrm{f})$ machen deutlich, dass der Verfasser Jesus bewusst mit Mose gleichsetzen will.

(Tuor-Kurth 2010:209)

Like Pharaoh's, Herod's decision is politically motivated. In addition, the latter's politics towards rivals and challengers certainly may have played a role in Matthew's decision for shaping the story in this way. ${ }^{6}$ In both stories, Egypt is given a role, an opposite one, but the choice for Egypt as a place of protection was probably not motivated in the way Tuor-Kurth formulates it: 'Die ironische Tatsache, dass Mose aus Ägypten und Joseph nach Ägypten flieht, ergibt sich aus der Lokalisierung der Geburt des Davididen Jesus nach Bethlehem' (Tuor-Kurth 2010:209). The motif of Egypt as a safe haven has a longstanding tradition that is well attested in biblical texts. There surely is irony in it and this irony is additional proof that Matthew wanted to play on the two stories. Of course, there are differences. It is true, as Tuor-Kurth notes, that the king's decision to slaughter all new-borns is mentioned only after the child is born and as a second option after the first one had failed. It is also true that the flight, in the company of the parents, renders exposition unnecessary, unlike in the Moses story. ${ }^{7}$ However, Matthew 2:13-16 is not a copy of that Moses episode; it has been inspired by it and with a purpose - the illustration of the troublesome birth of the new Moses. It is the latter that counts; the details do not matter that much. ${ }^{8}$ It is also worth noticing that the parallel with Moses is not limited to the sole massacre scene. The way Joseph is informed to flee and organises himself in Matthew 2:13 clearly has been inspired by Exodus 4:19-20 (Brown 1993:215, 617; Allison 1993:144). Moses plays a kind of double role. Of course, this story of the flight to Egypt is not exhausted by the sole reference to Exodus 4:19-20. Most probably, other motifs and other biblical characters are involved as well. There is an evident allusion to the exile here ${ }^{9}$ and maybe to those other figures of Israel's past that once went down to Egypt, Joseph in the first

6.The most telling illustration that is always cited and that has a long history in modern exegesis is a passage from Macrobius (Saturnalia 2.411) writing in around 400 . He 'cites' the emperor Augustus' reaction on hearing about Herod's cruelty after he 'cites the emperor Augustus' reaction on hearing about Herod's cruelty after he an obvious play on îs ['pig'] and viós ['son']). See Wettstein (1752/1962:251-252).

7.Tuor-Kurth (2010:210) thinks the suggestion that the flight motif would reflect a critique of the exposition praxis (Cohen 1993:167) is 'eine ansprechende Vermutung', but finally decides for the (better) option that this cannot be proven as it is an argument from silence only.

8.It is important in such matters not to overstate things. Tuor-Kurth has moved into that direction when trying to build something of a chiasm in comparing the stories of Moses and Jesus being threatened. As she puts it, in the Moses story it is first 'all new-borns' that are threatened (and preserved) and then the one child Mose (who is saved); in Matthew's story it is the child Jesus that is threatened (and preserved by the magi fleeing Herod) and then the whole mass of new-borns (with Jesus escaping). The chiasm does not work to its full strength because in Exodus 2 Moses is not directly and personally threatened by Pharaoh, but exposed to evade a possible danger.

9.This has been noted by several authors, quite emphatically by Brown (1993:216 who after referring to the parallel with the massacre, continues, 'But Matthew works to connect this event in Egypt with another major tragedy in Israelite history, the Exile of the tribes to Assyria and Babylon. In the theology of Israe the persecution in Egypt and the Exile were the two greatest trials to which God's people had been subjected; and the Exodus and the return from Exile were the two greatest manifestations of Yahweh's protective power'. In addition, Jesus had lived them both and already as a child. place, maybe Jacob or Israel fleeing from Laban. ${ }^{10}$ However, it is obviously Moses, above all others, who plays the star role and this is certainly so for the motif of the massacre. He is the only one of these other parallel characters who is threatened as a child and who escapes a mass massacre. ${ }^{11}$ What does all of this add to Van Aarde's story? I think it matters quite a lot, for the link with Moses makes Jesus 'honourable' in yet another way than the one indicated by Van Aarde. Matthew's is not just a 'talk of two kings', it is a talk about the evil king and the new Moses who is much more than any king ever will be. Hence, should there not also be given a place in the manger to Moses?

Jesus was 'fatherless', perhaps also in a double sense. His earthly father was not his natural father and maybe that father had died soon after whilst Jesus was still a child. As is well known, the latter has been suggested by several early Christian authors, either indirectly by making Joseph 'a very old man' (so the Protevangelium of James 10.1) or by explicitly adding that Joseph had passed away (Epiphanius, Panarion 78.10). Van Aarde (2001:115-116) is critical of both options, especially of Epiphanius. ${ }^{12}$ It cannot be denied that Joseph suddenly disappears from the gospel and is never mentioned again or alluded to in the spare references to Jesus' family later on in the gospel. However, he would not be the only one to fade away in this manner in biblical texts. The boy Samuel, who was born to Elkanah and his wife Hannah, soon was separated from his parents and raised by the priest Eli, meeting his parents only once a year 'while he grew up in the presence of the Lord' (1 Ki 2:21, 26). This phrase returns three times, like a refrain, in Luke's Infancy narrative, both for John and for Jesus $(1: 80 ; 2: 40,52)$. Elkanah is mentioned several times in 1 Kings 1-2 (LXX 1:1, 4, 8, 19, 21, 23; 2:20), but

10.Brown (1993:544) thinks the second of these interpretations to be slightly less convincing, but he does not wish to exclude it. The fact that Moses does not actually 'flee' to Egypt, but returns there (Ex 4:19-20) should not be held against a possible parallel. As Brown indicates, they are all part of the same story: 'it was
Joseph who arranged for Jacob/Israel to come to Egypt and it was Moses who Joseph who arranged for Jacob/Israel to come to Egypt and it was Moses who
led Israel out of Egypt, and Jacob may be said to have returned from Egypt in the led Israel out of Egypt, and Jacob may be said to have returned from Egypt in the
person of his descendants'. Moses and Joseph (and Abraham!) find themselves person of his descendants'. Moses and Joseph (and Abraham!) find themselves
together also in the two other passages in the New Testament that refer to the together also in the two other passages in the New Testament that refer to the
troublesome birth of Moses. This is most clearly the case in Acts 7:17-21, but it troublesome birth of Moses. This is most clearly the case in Acts 7:17-21, but it
is also true for that other passage, Hebrews 11:23, which itself is part of a longer evocation of Israel's history from the time of the Patriarchs on and, in addition, also links in Moses with Jesus by almost 'shamelessly' Christianising the former in v. 26 (Saito 1977:106; Lang 1977:105; Weiss 1991:607: 'Mose ... wird hier geradezu als ein 'idealer Christ' verstanden'). Both passages are discussed also in Tuor-Kurth (2010:203-208).

11.The story of young Moses and young Jesus is a most appealing one. It therefore does not come as a surprise that it has been developed and been transposed to other major characters of Jewish history in later tradition and that a similar story about a new-born being threatened by a (wicked) king rushing to this most cruel about a new-born being threatened by a (wicked) king rushing to this most cruel
act of mass infanticide was told also in Roman circles (Suetonius, Div. Aug. 94, on the announcement of the birth of the later emperor Augustus, with the senate in the role of the 'bad guys' deciding to kill all new-borns and some senators whose
wives were pregnant trying to escape this fate in the hope that their son might be wives were pregnant trying to escape this fate in the hope that their son might be
the prodigal one!). Brown (1993:543) refers to Ginzberg (1909:186-187, 207-209) the prodigal one!). Brown (1993:543) refers to Ginzberg (1909:186-187, 207-209),
for traditions on the child Abraham threatened by the wicked king Nimrod who is for traditions on the child Abraham threatened by the wicked king Nimrod who is
advised to slaughter all male children. This material (and some other) had been collected and discussed two years earlier by Wünsche (1907:1, 14-34). For the further development of the Moses story in extra-biblical and later Jewish tradition, see Allison (1993:157-159). For the evidence from Suetonius, scholars tend to cite Broer (1981:83; see Brown 1993:615), but in note 26 one will find evidence that the parallel has been around in scholarly literature already for a much longer period (references to Usener, Norden, Clemen). Greek and Roman evidence for exposing new-borns (of royal descent) was discussed by Binder (1964) and now by Tuor-Kurth (2010:29-79). Suetonius and the Abraham material are also cited in Boring, Berger \& Colpe (1995:43-44)

12.'I cannot see how Meier could seriously consider the patristic evidence as historically authentic' (Van Aarde 2001:115-116). However, the same criticism applies to the alternative Van Aarde suggests, for what evidence do we have that Joseph had abandoned his family? 
after 1 Kings 2:20 he disappears without leaving a trace. Had he passed away? Manoah and his wife are finally granted a son. Samson lives with his parents 'while growing up' (Jdg 13:24-25) and stays in touch with them after he had become an adult, even returning to his father's house after his failed marriage (14:19). The father is not mentioned anymore, but in Judges 16:31, the reader is told he had passed away before Samson was murdered. Was the phrase 'his father's house', instead of 'his father', already an indication that the father had died? It seems it is not possible to come to a clear conclusion; the child Jesus would have been 'fatherless' at least in the first sense mentioned earlier.

This child then grew up an adult who will always show great consideration for children, especially then for children in need or have been abandoned, as is the case in the so-called 'Evangelium Infantium' in Mark 10:13-16 and parallels (Mt 19:13-15 and Lk 18:15-17). That is what Van Aarde (2001) is arguing in the first part of Chapter Six:

it is possible to consider these children, from a perspective of the social stratification of first-century Herodian Palestine, as part of the lowest class, namely, the 'expendables'. Neither Mark nor its parallel texts in the other Gospels refer to parents bringing these children to Jesus. It seems that the children were street urchins.

(Van Aarde 2001:136)

I had noted in the margin, 'Does this hold?' That is what I now propose to look into.

\section{Mark 10:13-16}

The children of Mark 10,13-16 and its parallels are not further identified in any way in any of the gospels, apart from the fact that Luke in the first instance calls them $\beta \rho \epsilon ́ \phi \eta$ ['infants'] (18:15), but then returns to Mark's maısia ['children']. No help can be found in this respect from that other passage mentioning Jesus with children in Mark 9:36-37 and parallels (Mt 18:2-5 and Lk 9:47-48). As one could expect, this is like an open invitation to biblical scholars for giving these children an identity and a wide range of suggestions can be cited, from children of community members (related to baptism) to abandoned children that were taken care of by Christians to Ignatius of Antioch (Tuor-Kurth 2005:90)!13 In itself, it is of course not impossible that Mark has Jesus here refer to abandoned children. The early Christians were evidently familiar with such a phenomenon and there is evidence from a later period that the church tried to cope with it in a realistic and cautious way (Tuor-Kurth 2010:344-345). However, it is the evidence from Mark and parallels that cause me problems and make me hesitate. Van Aarde (2001:138) refers to Schmithals for an interpretation of Mark 10:13-16 'against the background of the healing of ostracized children'. That is precisely what Schmithals does: it is a possible background, not identification proper. ${ }^{14}$ Van Aarde (2001:140-144) cites an

13.Several scholars assume that one or another form of social act is involved though they remain divided on what it may have involved. On the identification in early Christian tradition of the child in Mark 9:36 with Ignatius, see Grundmann [1980:262-263] (with reference to Lightfoot's commentary on the letters of lgnatius).

14.Schmithals (1986:447). In commenting on Mark 10:13-16 Schenke (1988:135), noted in a somewhat similar way: 'Die Versorgung von Findelkindern und Waisen ist der besondere Dienst des Jesusjünger'. The combination with widows indicates that the author is not particularly focused on the children in the passage. Earlie on in the book Schenke had put forward an alternative view which in my opinion interesting number of instances, from old and recent times, on the praxis and consequences of exposing children, but as said, they do not prove the case for Mark. As a matter of fact, as I see it, Van Aarde mentions only one argument that is based on the text and that, in my view, does not hold. It is of course correct that the scene in Mark 10:13-16 and parallels contains several words and motifs that are typical for healing

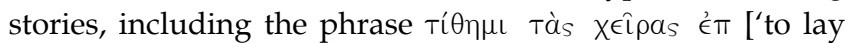
his hands upon'] (Mk 10:16; Luke omits it; Matthew has the

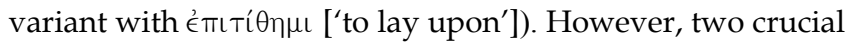
elements are lacking in all three versions. It is, firstly, the diagnosis and secondly, the motif of the suppliant '(aspiring at) being healed'. It is not said what these children that are brought to Jesus are suffering from. Neither they themselves, nor those who bring them to Jesus, ask for healing; it is not said that they are healed in some way. I am afraid this is lethal for the hypothesis. Van Aarde (2001:138) tries to remedy this

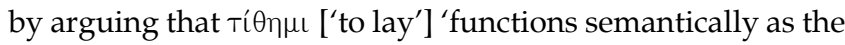

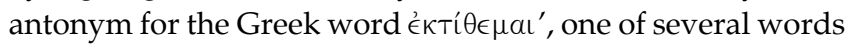
denoting 'to expose children'. That is simply not documented and in Acts 7:17-21, when referring to the scene of Moses being exposed, the antonym of é $\kappa T^{\prime} \theta \in \mu a \mathrm{l}$, which occurs twice

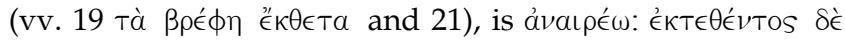

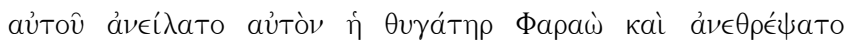

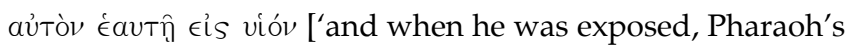
daughter adopted him and brought him up as her own son'] (v. 21). ${ }^{15}$ Van Aarde also builds on the double motif of Jesus 'embracing' (or, 'taking in his arms') 'and blessing the children' that is combined with that of laying hands upon

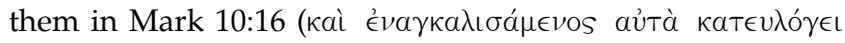

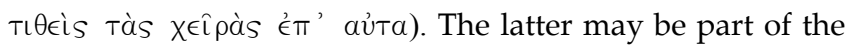
ritual of a father accepting a new-born in his house as Van Aarde (2001:139) indicates, but at most it can be said that Jesus is giving an example to others of how one should behave; he does not, however, regard it as something to which he is now bound, for right after he just leaves the child behind and

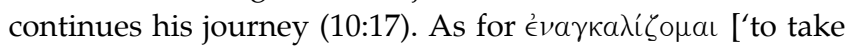

\section{(Footnote 14 cont...)}

is even less plausible and certainly not rooted in the text, when explaining the is even less plausible and certainly not rooted in the text, when explaining the passage against the background of persons leaving behind their partner and
children to follow Jesus (42), quite an embarrassing situation! A rather more children to follow Jesus (42), quite an embarrassing situation! A rather more
plausible way of involving (the) parents in the saying is suggested by Collins (2007), whilst not excluding the possibility that the saying in 9:36-37 was mean as an exhortation for Christians to 'welcome' exposed children, Collins (2007:446) prefers the alternative that it was a warning against continuing such a practice amongst Christians, but in the end settles for a more general understanding when noting, 'the issue is whether children ought to be welcomed as members of the community or welcomed at communal gatherings' (Collins 2007:445).

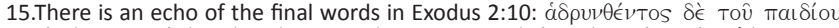

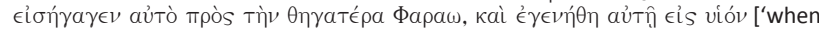
the child grew up, she brought him to Pharaoh's daughter, and she took him as her son']. The latter part of the phrase is a less technical way of describing an adoption, which is made 'official' (though, of course, it all has to be kept secret) by

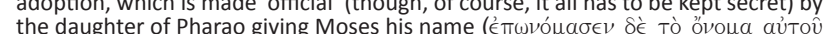

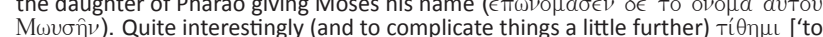
M $\omega v \sigma \eta \nu$ ). Quite interestingly (and to complicate things a little further) Ti $i \eta \mu$ [ ['to
lay'] and ajnairevw ['to take up'] both also occur in the same context of Exodus 2 and to denote an act that technically is one of exposing and adopting, but they are not used as technical terms - and that makes all the difference - and the former of these is not part of the phrase 'to put his hands on' as in Mark. Indeed, in reaction to Pharao's plan to 'throw' the new-born in the river (1:22 pí $\pi T \omega$, which indeed is a technical term for exposing children, though all hangs on the location: if there are 'thrown' into the river they will most likely be drawn before anyone finds them!)

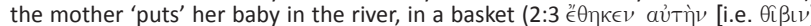

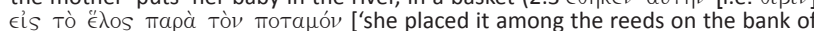
the river']). From there it is 'taken up' or 'drawn out' by the slave-girl and that is the reason why Moses is given his name (see 2.5 a

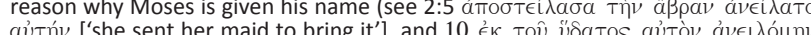

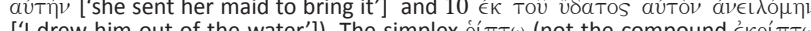
['I drew him out of the water']). The simplex $\rho i \pi T \omega$ (not the compound $\epsilon \kappa \rho i \pi T \omega$ as Van Aarde has it) is the verb used in the Letter to Diognetus 5.6 for exposing vita Mosis 1.8-24, clearly in dependence on Exodus 2 and Ps.-Phocylides 184-185).
vildren 
on one's arms'], this verb is attested in a context of a healing by a god, but then this is also said with so many words. ${ }^{16}$

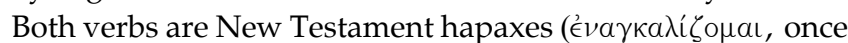
more in the closely parallel text of Mark 9:36) and they have both been dropped by Matthew and Luke. ${ }^{17}$ This is rather embarrassing if one wants to connect this passage with Jesus' own experience as a 'fatherless' child, for the link would then exist only through Mark, who never mentions Joseph at all and has the crowds refer to Jesus as a carpenter in his own right (Mk 6:3), not as the son of a carpenter (so Mt 13:55) or of Joseph (Lk 4:22). ${ }^{18}$

In line with Van Aarde, Tuor-Kurth (2005:99) has argued that Mark 9:35-37 (and Mk 10:13-16) should be understood against the background of the widespread phenomenon of abandoned children, including orphans but also children (not necessarily new-born only) that had been given up by their parents out of sheer poverty. ${ }^{19}$ The latter practice is well known and documented from ancient sources (TuorKurth 2005:92-95). The practice is not formally described nor condemned by Mark, but there was no need for it, as every good Christian would evidently abhor the practice. It is not described, but used by Jesus to make a statement on what Christian communities should do:

Hier hat sich die Realität niedergeschlagen, ohne dass ein Diskurs darüber geführt wird. ... Die Aussetzung selber wird hier nicht reflektiert, möglicherweise aber die Situation für solche Kinder, die der Hunger dazu tribe, Anschluss an die Jesusnachfolge zu suchen. Im Text könnte die Diskussion darum gehen, ob die Jesusbewegung sich damit belasten will. Jesus entscheidet: ja.

(Tuor-Kurth 2005:96-97)

The problem with this thesis is that the evidence is all indirect and circumstantial, that the solution Jesus proposes is laudable but his own handling remains somewhat ambivalent and that the other evangelists do not seem to have followed Mark in this. It may be true that there was probably no need to formally condemn the practice, but why not call these children for what they really are, orphans or

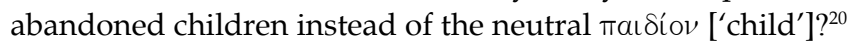

16.Van Aarde (2001:138) cites a passage from Diodorus Siculus (3.58.1-3) on Cybele embracing children 'and saving (i.e. healing) them' [ $\sigma \omega \hat{\zeta} \zeta \omega]$.

17.Luke has a paraphrase for it in 2:28 with old Simeon taking the baby Jesus in his arms and blessing God [ $\epsilon \dot{\jmath} \lambda o \gamma \in \hat{\epsilon} \omega]$. The act here is rather one of grace and thanksgiving. The parallel in Luke is noted by Tuor-Kurth (2005:97).

18.Van Aarde has essentially repeated this argumentation in a later article, but now also focusing on a specific feature of Matthew's dealing with the motif of Jesus and the children, as Matth Van Aarde 2004:139-140). They appear there in the presence of 'lame and blind" that are healed by Jesus (v. 14), but it is not said that the children are amongst or identical with these seeking healing (and Van Aarde does not say so either). The scene balances between a vivid picture of a daily life situation, with children repeating what they had heard others shouting to Jesus (Mt 21:9) and a quite improbable setting, with children being present in the Temple, where they were not allowed to be. The latter also applies to the blind and the lame and is an additional indication that the whole scene is not to be taken literally and rathe was constructed by Matthew in view of the quotation from Psalm 8:3 with which he creates an elegant cross-reference to that other saying of Jesus on the vímior ['babes'] in Matthew 11:25.

19.'es (kann) sinnvoll sein, die in Mk 9,36-37 aufgenommene vormarkinische Tradition dem in der Antike geführten Diskurs über die aus Armut geschehene Kindesaussetzung zuzuordnen'. One should note the somewhat hesitant tone.

20.The word ópфavós ['orphan'] occurs as a variant reading in Mark 12:40 (with widows) and further in John 14:18 (as a metaphor) and James 1:27 (visiting
Jesus speaks of 'receiving' the child. $\Delta$ éxorar ['to receive'] is not meant as a technical term for a father - head of a household - adopting or formally recognising a (newborn) child (Tuor-Kurth 2005:96, 2010:344). ${ }^{21}$ It does not mean, of course, that Jesus is saying Christians should only care about providing food to such children, but no shelter. The latter may also have been intended, but Jesus is not pushing towards formally adopting these children into the household, which is a legal procedure with all the consequences it has. Therefore, he takes a reasonable stand. On the other hand, his own involvement (embracing the child) is limited to a merely symbolic act of showing concern and offering protection that is not materialised in any way. ${ }^{22}$ Finally, there are the other gospels. If Mark were perhaps referring to children being abandoned, it seems the allusion was lost on Luke and Matthew, as Tuor-Kurth observes. For Luke the whole act is about showing what it means to be 'the least of all' (2005:98). Matthew, who has 'imported' a verse (18:3) from Mark 10:1316 (v. 15) into his parallel of Mark 9:36-37, thereby probably showing that he wants these two texts to be read in light of each other, also goes his own way. As Tuor-Kurth notes, 'Matthäus 18, 1-5 geht es nicht um die Kinderaufnahme, sondern um die Kinder als sozial Niedriggestellte, die zum Vorbild für ein Sozialverhalten werden' (Tuor-Kurth 2005:98). ${ }^{23}$ In addition, one could say that the motif of humility that Matthew connects with the child in Matthew 18:4 is perhaps not a particularly apt one for referring to street children. Of course, one can and should be moved by the tragedy and situation of such children (Mark may have had too 'romantic' a view on it), but are they really the best choice for representing a model of voluntary humility? Street children naturally raise compassion and those amongst them who have come to accept their position might erroneously be considered to be such a model. But evidence from past and present shows that many others can probably better be called models of resilience. They are survivors in a jungle, often ready to take on whatever it needs to be just that. It is no wonder then that the early Church has never tried to connect this passage with the a concern for caring for abandoned

(Footnote 20 cont...)

and taking care of widows and orphans); трє́тTos, the 'technical term' in the sources for exposed children is not used. Is it a matter of respect on the part of Mark's Jesus, or an indication that such categories are not specifically in view?

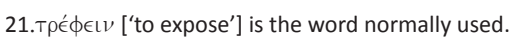

22.This is repeatedly emphasised by Tuor-Kurth (2005:97): 'Das Umarmen von Kindern kann etwa den Aspekt der Versorgung eines verwaisten bzw. Kranken Kindes symbolisieren. ... Mit der geste des Umarmens wird ausserdem der Schutz betont, den eine Mutter ihrem Kinde gibt' and 'In der markinischen Geste des Umarmens schwingen dise Aspekte der materiellen Versorgung, Geste des Umarmens schwingen diese Aspekte der materiellen Versorgung, des Schutzes, der Zugehorigkeit von Kindern m.E. mit. Als 'symbolische Vorwegnahme' von V. 37 exemplifiziert sie, was die geforderte Aufnahme von Kindern beinhalten soll' (Tuor-Kurth 2005:98). On the other hand, she also tries to handle the material aspect as well, arguing that such children would have seeked to join die wandernde Jesusbewegung ... Ihre Aufnahme ware dann nicht in ein Haus geschehen' (Tuor-Kurth 2005:97). But how should one imagine this, in real life'? How close does this come, on the part of Jesus, to merely showing 'some concern' or a 'liebende Zuwendung' towards children, as Tuor-Kurth (2005:90) describes Müller's (1992:291) position. In the same line as the latter, see Gnilka (1979:57): 'Die Umarmung - gelegentlich auch ein Heilsgestus - ist Ausdruck der Liebeszuwendung'. On the pre-Markan level 10:13-16 would be a critique of the commonly accepted 'Verdienstdenken' by claiming that even children who have no knowledge of the Law can enter the Kingdom; on the level of Mark it would be a model and mirror for the disciples (Tuor-Kurth 2005:81).

23.According to Marcus (2009:683), this would also be the meaning of Mark 10:13-15, but not of 9:36-37 that has in view 'real children'. Marcus (2009:682) lists several possibilities of what this service to children might consist of, including the one mentioned by Schenke (temporarily leaving behind one's children for missionary work; see above) and the possibility that it alludes to children whose parents had work; see above) and the possibility that it alludes to children whose parents had
become the victims of persecution; Stegemann (1980:129-130). However, what become the victims of persecution; Stegemann (1980
evidence is there for the latter in the text of Mark? 
children, but rather with the question whether children of community members should have access to baptism (TuorKurth 2005:98); maybe this is still the safer option after all (Lindemann 2009:109-134, 2010:187-190).

At one point in his analysis, Van Aarde cites a long quotation from a book by James Veitch on the historicity of the Infancy narratives which ends as follows: 'So forget the history and enjoy the myth' (2001:148). Joy can be found in many things and I guess some can find it even in retirement. I hope this will also be the case for our honouree, my little critical note and friendly warning regarding his intriguing hypothesis notwithstanding.

\section{References}

Allison, D.C., 1993, The New Moses: A Matthean Typology, T\&T Clark, Edinburgh.

Binder, G., 1964, Die Aussetzung des Königskindes Kyros und Romulus, Hain, Meisenheim. (Beiträge zur klassischen Philologie 10.)

Boring, M.E., Berger, K. \& Colpe, C., 1995, Hellenistic Commentary to the New Testament, Abingdon, Nashville, TN.

Broer, I., 1977-1978, 'Die Kindheitsgeschichte im Matthäusevangelium und die neuere Exegese', Siegener Pädagogische Studien 23, 46-55.

Broer, I., 1981, 'Jesusflucht und Kindermord - Exegetische Anmerkungen zum zweiten Kapitel des Mattäusevangeliums', in R. Pesch (Hrsg.), Zur Theologie der Kindheitsgeschichten. Der heutige Stand der Exegese, pp. 74-96, Schnell \& Steiner, München/Zürich

Brown, R., [1977] 1993, The Birth of the Messiah: A Commentary on the Infancy Narratives in the Gospels of Matthew and Luke, Doubleday, New York.

Cohen, J., 1993, The Origins and Evolution of the Moses Nativity Story, Brill, Leiden.

Ellens, J.H. \& Rollins, W.G. (eds.), 2004, Psychology and the Bible: A New Way to Read the Scriptures, vol. 4, From Christ to Jesus, Praeger, Westport, CT.

Fiedler, P., 2006, Das Matthäusevangelium, Kohlhammer, Stuttgart. (ThKNT 1.)

Ginzberg, L., 1909, Legends of the Jews, I, JPS, Philadelphia.

Gnilka, J., 1979, Das Evangelium nach Markus, Benziger, Zürich/Neukirchener, Neukirchen-Vluyn. (EKK II/2.)

Grundmann, W., ${ }^{8} 1980$, Das Evangelium nach Markus, Evangelische Verlagsanstalt, Berlin. (ThHNT 2.)

Lindemann, A., [1983] 2009, 'Die Kinder und die Gottesherrschaft: Markus 10, 13-16 und die Stellung der Kinder in der späthellenistischen Gesellschaft und im Urchristentum', Wort und Dienst 17 (1983) (repr. in Die Evangelien und die Apostelgeschichte, Mohr Siebeck, Tübingen, 2009, pp. 109-134). (WUNT 241.)

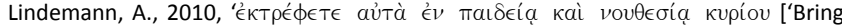
them up in the discipline and instruction of the Lord'] (Eph 6.4): Kinder in der Welt des frühen Christentums', New Testament Studies 56, 169-190. doi: 10.1017/ des frühen Christent
S0028688509990257

Marcus, J., 2009, Mark 8-16, Yale University Press, New Haven/London. (Anchor Bible.)

Mayordomo-Marin, M., 1998, Den Anfang horen: Leserorientierte Evangelienexegese am Beispiel von Matthäus 1-2, Vandenhoeck \& Ruprecht. Göttingen. (FRLANT 180.)

Merx, A., 1902, Das Evangelium Matthaeus nach der syrischen im Sinaikloster gefundenen Palimpsesthandschrift, Reimer, Berlin.

Miller, J.W., 1997, Jesus at Thirty: A Psychological and Historical Portrait, Fortress, Minneapolis, MN

Müller, P., 1992, In der Mitte der Gemeinde: Kinder im Neuen Testament, Neukirchener, Neukirchen-Vluyn.

Saito, T., 1977, Die Mosevorstellungen im Neuen Testament, P. Lang, Bern/Frankfurt. (EHS 23/106.)

Schenke, L., 1988, Das Markusevangelium, Kohlhammer, Stuttgart. (UTB 405.)

Schmithals, W., ${ }^{2} 1986$, Das Evangelium nach Markus, Mohn, Gütersloh/Echter, Würzburg. (OTKNT 2/2.)

Schweitzer, A., 1948, The Psychiatric Study of Jesus: Exposition and Criticism, transl. C.R. Joy, Beacon Press, Boston.

Stegemann, W., 1980, 'Lasset die Kinder zu mir kommen: Sozialgeschichtliche Aspekte des Kinderevangeliums', in W. Schottroff \& W. Stegemann (Hrsg.), Traditionen der Befreiung. Sozialgeschichtliche Bibelauslegungen, I., pp. 114-144, Kaiser, München.

Tuor-Kurth, C., 2005, 'Nochmals: 'Wer eines solcher Kinder aufnimmt'. Ein Beitrag zur sozialgeschichtlichen Auslegung von Mk 9, 35-37', in G. Gelardini (Hrsg.), Kontexte der Schrift. Text, Ethik, Judentum und Christentum, Gesellschaft. Ekkehard W. Stegemann zum 60, Geburtstag, pp. 87-99, Kohlhammer, Stuttgart.

Tuor-Kurth, C., 2010, Kindesaussetzung und Moral in der Antike: Jüdische und christliche Kritik am Nichtaufziehen und Töten neugeborener Kinder, Vandenhoeck \& Ruprecht, Göttingen. (Forschungen zur Kirchen- und Dogmengeschichte 101.)

Van Aarde, A., 2001, Fatherless in Galilee: Jesus as Child of God, TPI, Harrisburg, PA.

Van Aarde, A., 2004, 'Jesus' Affection towards Children and Matthew's Tale of Two Kings', Acta Theologica 24, 127-146.

Van Os, B., 2010, 'The Role of Psychology in the Search for the Historical Jesus and His Earliest Followers', paper read at the annual meeting of the Studiosorum Novi Testamenti Conventus, Soesterberg, 14th June.

Weiss, H.-F., 1991, Der Brief an die Hebräer, Vandenhoeck \& Ruprecht, Göttingen. (KEK 13.)

Wettstein, J.J., 1752, Novum Testamentum Graecum, Dommerian, Amsterdam (repr. 1962, Akademische Druck- und Verlagsanstalt, Graz).

Wünsche, A., 1907, Aus Israels Lehrhallen. I.1., Henrichs, Leipzig.

Yarbro Collins, A., 2007, Mark: A Commentary, Fortress, Minneapolis, MN. (Hermeneia.) 